\title{
Tinnitus Rehabilitation Effects Using Partial Masking with Nature Sounds
}

\author{
Seungyeop Jeong', Sohee Heo', Hongyeop Oh', Jeeun Yoo', In-Ki Jin² \\ 'Department of Speech Pathology and Audiology, Graduate School, Hallym University, Chuncheon, Korea \\ ${ }^{2}$ Division of Speech Pathology and Audiology, Research Institute of Audiology and Speech Pathology, College of Natural Sciences, \\ Hallym University, Chuncheon, Korea
}

\author{
자연음을 활용한 부분 차폐의 이명 재활 효과 \\ 정승엽 ${ }^{1} \cdot$ 허소희 ${ }^{1} \cdot$ 오홍엽 ${ }^{1} \cdot$ 유제은 ${ }^{1}$ 진인기 ${ }^{2}$ \\ 한림대학교 일반대학원 언어병리청각학과', 한림대학교 자연과학대학 언어청각학부 · 청각언어연구소 ${ }^{2}$
}

\begin{abstract}
Purpose: The purpose of the current study was to identify tinnitus rehabilitation effects using partial masking with nature sounds. Methods: Nineteen people who had chronic subjective tinnitus participated in this study. Each participant was randomly assigned to one of two groups: counselling and sound therapy using nature sounds or counselling and sound therapy using broadband noise (BBN). Two types of nature sounds were used: the sound of waves and the water of a stream. The partial masking was applied to the sound therapy in both groups and the rehabilitation period was three months. The Tinnitus Handicap Index was administered before and after the rehabilitation. Results: The average decrease in tinnitus as shown by the questionnaire was $15.92 \%$ for the nature sound therapy group and $8.43 \%$ for the BBN therapy group. Statistical significance was observed only in the nature sound therapy group $(p<0.05)$. For effect size (Cohen's d) of the tinnitus rehabilitation, the nature sound therapy group was 1.03 (large effect) and the BBN therapy group was 0.58 (moderate effect). Conclusion: Results of the current study showed that sound therapy using nature sounds was more effective than sound therapy using BBN in a short period of tinnitus rehabilitation. Although further studies are required, results of the current study indicate that the effect of the tinnitus rehabilitation may differ, depending on the characteristics of the sound stimulus.
\end{abstract}

Key Words: Tinnitus, Masking, Tinnitus rehabilitation, Sound therapy, Subjective tinnitus treatment.

Received: October 13, 2018 / Revised: December 12, 2018 / Accepted: January 4, 2019

Correspondence: In-Ki Jin, Division of Speech Pathology and Audiology, Research Institute of Audiology and Speech Pathology, College of Natural Sciences, Hallym University, 1 Hallymdaehak-gil, Chuncheon 24252, Korea

Tel: +82-33-248-2221 / Fax: +82-33-256-3420 / E-mail: inkijin@hallym.ac.kr

\section{INTRODUCTION}

이명(tinnitus)은 외부 자극과 무관하게 대상자가 주관적으 로 소리를 지각하는 증상을 의미하며 다양한 방식으로 분류할 수 있지만, 보편적으로 발생 기전을 파악할 수 있는 객관적 이 명(objective tinnitus)과 발생 기전을 알 수 없는 주관적 이명 (subjective tinnitus)으로 분류할 수 있다(Jastreboff, 1990). 객 관적 이명의 경우에는 원인에 대한 치료를 위해 약물 요법 등의 접근법이 고려될 수 있으며, 일반적으로 높은 치료 효과를 기

(c) This is an Open Access article distributed under the terms of the Creative Commons Attribution Non-Commercial License (https://creativecommons.org/licenses/by-nc/4.0) which permits unrestricted non-commercial use, distribution, and reproduction in any medium, provided the original work is properly cited.
대할 수 있다(Robinson et al., 2007). 하지만 주관적 이명의 경 우에는 발생 기전의 파악에 어려움이 있어 직접적인 치료에 한 계가 있으며 대부분 만성 이명으로 진행되는 경우가 많고 이명 소리에 따른 고통을 포함하여 수면장애, 집중력 저하 등의 부 작용이 동반되어 이명 대상자의 삶의 질을 현저히 저하시킬 수 있다(World Health Organization, 2001).

주관적 이명의 치료는 주로 이명에 대한 부정적인 인식을 바 꾸거나 이명으로 인한 스트레스를 감소시키기 위한 재활 요법 이 고려될 수 있으며 상담(counseling)과 소리치료(sound ther$\mathrm{apy)}$ 는 다양한 재활 요법 중에서 보편적으로 적용되는 재활 방 법이다(Del Bo et al., 2010; Jastreboff \& Hazell, 1993). 상담 은 대상자의 이명에 대한 이해를 통해 이명으로 인한 두려움과 
근심을 줄일 수 있으며, 이명 재활의 필요성과 과정에 대한 이 해도를 증가시켜 이명 재활에 대한 동기부여를 제공하는 등 대 상자가 이명을 극복하도록 심리적인 지지를 위한 방법으로 주로 적용된다(Tunkel et al., 2014). Tyler et al.(2012)은 18개월 동안 상담만을 시행한 18 명의 이명 재활군에서 이명 설문지 점수의 변화를 기준으로 약 $25 \%$ 의 재활 효과가 나타났다고 보고하였 다. 따라서 상담은 이명 재활에서 매우 중요한 요소 중 하나라 고 볼 수 있다. 소리치료는 다양한 접근법들이 존재하는데 보 편적으로 재활의 효과가 입증된 방법들은 이명 소리의 차단에 초점을 두는 차폐(masking), 이명에 대한 습관화(habituation) 를 유도하는 이명재훈련치료(Tinnitus Retraining Therapy), 이 명 소리에 과도하게 집중된 청각 체계의 재조직화(reorganization of auditory system)를 유도하는 노치형 소리치료(notched sound therapy) 등이 있다(Henry et al., 2006; Lugli et al., 2009; Tyler et al., 2012). 일반적으로 소리치료는 단독으로 적 용되기보다는 상담과 함께 시행하는데 Henry et al.(2006)은 이명의 정도를 대상자가 느끼는 고통에 따라 세 그룹(중간 정 도 영향, 큰 영향, 매우 큰 영향)으로 구분하여 상담과 소리치료 를 병행하여 재활을 시행한 결과 세 그룹 모두 이명 설문지 점 수의 유의미한 감소가 나타났다고 보고하였다.

다양한 소리치료 접근법 중 차폐 방식은 대상자의 이명에 대 한 지각을 감소시키는 것을 재활의 주요 목적으로 하며 주로 백 색 소음(white noise)을 필터링한 광대역 소음(broadband noise, $\mathrm{BBN}$ )을 음원으로 사용한다(Vernon, 1977). 차폐 방식은 소리 치료 음원의 강도 설정 방식에 따라 이명 소리를 완전히 차폐 하는 방식(total masking)과 이명 소리가 간헐적으로 인지되는 강도 수준으로 낮추어 강도를 설정하는 부분 차폐(partial masking)로 구분할 수 있다. 일반적으로 완전 차폐 방식은 부분 차폐보다 즉각적인 이명 소리의 차폐 효과가 두드러진다고 보고 하고 있으며 부분 차폐는 완전 차폐 방식보다 이명의 완화(relief)에 더 도움이 된다고 알려져 있다(Hazell \& Wood, 1981). 몇몇 연구들은 이명재훈련치료 또는 노치형 소리치료가 장기적 인 관점에서 이명의 완화 효과가 차폐 방식보다 더 크다고 보고 하고 있지만, Tyler et al.(2012)은 차폐 방식의 소리치료와 이명 재훈련치료에서 사용하는 혼합점(mixing point) 수준의 소리 치료에 따른 재활 효과를 비교한 결과 두 방식 모두 유의미하 게 이명의 완화가 나타났으며 두 방식 간의 효과 차이는 유의미 하지 않았다고 보고하였다. 요약하면, 최근에는 이명의 완화 및 습관화 효과를 위한 다양한 접근법이 시도되고 있으나 기존의 전통적인 방법 중 하나인 차폐 방식 또한 이명의 완화에 도움 을 줄 수 있는 재활법 가운데 하나로 분류할 수 있다.

이명 재활의 효과는 소리치료의 접근 방식에 따라서도 영향 을 받지만 사용하는 자극음의 종류에 따라서도 영향을 받을
수 있다. 보편적으로는 광대역 소음 또는 협대역 소음(narrowband noise)처럼 백색 소음을 필터링한 소리를 음원으로 사용 하고 있지만, 장시간 청취가 요구되는 소리치료 재활에서 사용 하는 재활용 음원은 사용자가 선호하고 불편하지 않아야 한다 (Jastreboff \& Jastreboff, 2006). Henry et al.(2004)은 보편적 인 선호음 중 하나인 자연음이 소음과 비교하여 이명의 완화에 도움이 되는지 비교하기 위해 물소리 등 다양한 자연음과 소음 을 이명 대상자에게 들려주고 소리 음원을 듣기 전과 후의 이 명으로 인한 괴로움(annoyance) 정도를 비교한 결과 소리치료 음원을 들려주었을 때가 이명 소리만을 들었을 때보다 유의미하 게 괴로움이 줄어드는 것으로 나타났으며, 두 종류의 음원 중 자연음을 청취할 때가 소음을 청취할 때보다 괴로움이 유의미 하게 더 줄어드는 것으로 보고하였다. Henry et al.(2004)은 이 러한 결과를 자연음이 소음보다 역동적인 진폭 변화가 두드러 져 이명 소리에 대한 집중력 분산에 도움이 되며 자연음이 일 반적으로 선호음으로 분류되기 때문에 청취에 거부감이 적을 수 있다고 분석하였다. 하지만 Barozzi et al.(2016)은 소음 및 자연음 모두 소리치료에서 재활 효과가 나타났으나 두 음원 간 의 유의미한 차이는 발견되지 않았다고 보고하였다. 이처럼 자 연음과 같은 선호음이 이명 재활에서 소음보다 효과적인 음원 이 될 수 있는지 여부는 아직 불분명하며 추가적인 연구가 필 요한 실정이다.

본 연구의 목적은 부분 차폐 방식의 소리치료 재활에서 사용 하는 소리치료용 음원에 따른 이명 재활의 효과를 비교하고자 하였다. 소리치료 음원은 부분 차폐에서 보편적으로 사용되는 광대역 소음과 진폭의 역동성이 두드러지고 주파수별 에너지 분포가 넓은 자연음(파도 소리 또는 시냇물 흐르는 소리)을 사 용하였으며, 두 소리치료 그룹 모두 상담과 병행한 재활을 시행 하였다. 본 연구의 결과는 소리치료 음원의 특성에 따른 재활 효과를 비교하기 위한 하나의 증거 중심 자료(evidence-based data)를 제공할 수 있을 것이다.

\section{MATERIALS AND METHODS}

\section{Participants}

본 연구는 1년 이상 지속된 만성 이명으로 인해 불편함을 호 소하는 성인을 대상으로 진행하였다. 이명 관련 재활 또는 치료 를 현재 받고 있는 대상자, 청각과민증 진단을 받은 이력이 있 는 대상자 및 보청기를 포함한 청각 보조기기를 사용 중인 대 상자는 연구 결과에 영향을 줄 수 있어 본 연구의 대상자에서 제외하였다. 대상자 선정 후에 연구 참여자의 청력과 이명 특징 및 이명으로 인한 불편함을 파악하기 위하여 순음청력검사, 이 명도 검사(tinnitogram) 및 이명장애지수(Tinnitus Handicap 
Index) 설문지를 진행하였다. 연구 참여자는 광대역 소음을 사 용하는 재활 그룹(BBN group)과 자연음을 사용하는 재활 그 룹(Nature group)에 동일한 수(12명)로 무작위 할당되었다. 하 지만 3개월간의 재활 기간 동안 광대역 소음 기반 그룹에서 5 명의 대상자가 중도 포기하여 본 연구에서는 광대역 소음 그룹 7 명 및 자연음 그룹 12 명의 결과값을 기반으로 분석하였다. 중도 포기한 5명의 경우에는 포기 사유를 고찰에서 제시하였다. 모든 대상자는 실험 이전에 본 연구의 목적, 진행 절차 등에 대해 충 분한 설명을 들었고 각 참여자에게 연구 참여 동의서를 받고 검 사를 시행하였다.

그룹별 대상자 정보 및 이명장애지수 설문지 점수 및 이명 특징은 Table 1에 제시하였다. 광대역 소음 기반 재활 그룹(남자 3 명, 여자 4명)의 평균 연령은 72.4세[standard deviation (SD) = \pm 7.1 였으며 이명 재활 시작 전의 이명장애지수 설문지의 평 균 점수는 $39.3 \%(\mathrm{SD}= \pm 11.3)$ 였다. 본 그룹 오른쪽 귀의 경 우, $250 \mathrm{~Hz}$ 의 평균 역치는 $32.8 \mathrm{~dB} \mathrm{HL}$ (SD = \pm 9.9)로 나타났 으며, $500 \mathrm{~Hz}$ 에서는 $35.7 \mathrm{~dB} \mathrm{HL}(\mathrm{SD}= \pm 10.6), 1,000 \mathrm{~Hz}$ 에서 는 $34.3 \mathrm{~dB} \mathrm{HL}(\mathrm{SD}= \pm 10.6), 2,000 \mathrm{~Hz}$ 에서는 $41.4 \mathrm{~dB} \mathrm{HL}$ $(\mathrm{SD}= \pm 12.8), 4,000 \mathrm{~Hz}$ 에서는 $51.4 \mathrm{~dB} \mathrm{HL}(\mathrm{SD}= \pm 21.9)$, $8,000 \mathrm{~Hz}$ 에서는 $62.8 \mathrm{~dB} \mathrm{HL}(\mathrm{SD}= \pm 18.0$ )로 나타났다. 왼쪽 귀의 경우, $250 \mathrm{~Hz}$ 의 평균 역치는 $29.3 \mathrm{~dB} \mathrm{HL}(\mathrm{SD}= \pm 12.4$ ), $500 \mathrm{~Hz}$ 에서는 $32.8 \mathrm{~dB} \mathrm{HL}(\mathrm{SD}= \pm 11.1), 1,000 \mathrm{~Hz}$ 에서는 31.4 $\mathrm{dB} \mathrm{HL}(\mathrm{SD}= \pm 13.4), 2,000 \mathrm{~Hz}$ 에서는 $37.8 \mathrm{~dB} \mathrm{HL}(\mathrm{SD}= \pm$ 14.7), $4,000 \mathrm{~Hz}$ 에서는 $41.4 \mathrm{~dB} \mathrm{HL}(\mathrm{SD}= \pm 10.7$ ), $8,000 \mathrm{~Hz}$ 에 서는 $61.4 \mathrm{~dB} \mathrm{HL}(\mathrm{SD}= \pm 16.0$ )로 나타났다. 자연음 기반 재활 그룹(남자 7명, 여자 5명)의 평균 연령은 73.8 세 $(\mathrm{SD}= \pm 6.7$ )였 으며 이명 재활 시작 전의 이명장애지수 설문지 점수는 $33.0 \%$ $(\mathrm{SD}= \pm 18.4)$ 였다. 본 그룹 오른쪽 귀의 경우, $250 \mathrm{~Hz}$ 의 평균 역치는 $25.8 \mathrm{~dB} \mathrm{HL}$ ( $\mathrm{SD}= \pm 12.2$ 로 나타났으며, $500 \mathrm{~Hz}$ 에서 는 $25 \mathrm{~dB} \mathrm{HL}(\mathrm{SD}= \pm 10.2), 1,000 \mathrm{~Hz}$ 에서는 $30.8 \mathrm{~dB} \mathrm{HL}$ ( $\mathrm{SD}$ $= \pm 9.7), 2,000 \mathrm{~Hz}$ 에서는 $38.8 \mathrm{~dB} \mathrm{HL}(\mathrm{SD}= \pm 16.9), 4,000$ $\mathrm{Hz}$ 에서는 $44.2 \mathrm{~dB} \mathrm{HL}(\mathrm{SD}= \pm 19.2), 8,000 \mathrm{~Hz}$ 에서는 46.8 $\mathrm{dB} \mathrm{HL}(\mathrm{SD}= \pm 16.0$ )로 나타났다. 왼쪽 귀의 경우, $250 \mathrm{~Hz}$ 의 평균 역치는 $27.9 \mathrm{~dB} \mathrm{HL}(\mathrm{SD}= \pm 9.9), 500 \mathrm{~Hz}$ 에서는 $27.9 \mathrm{~dB}$ $\mathrm{HL}(\mathrm{SD}= \pm 8.4), 1,000 \mathrm{~Hz}$ 에서는 $29.6 \mathrm{~dB} \mathrm{HL}(\mathrm{SD}= \pm 14.7)$, $2,000 \mathrm{~Hz}$ 에서는 $37.1 \mathrm{~dB} \mathrm{HL}(\mathrm{SD}= \pm 21.3), 4,000 \mathrm{~Hz}$ 에서는 $43.8 \mathrm{~dB} \mathrm{HL}(\mathrm{SD}= \pm 23.3), 8,000 \mathrm{~Hz}$ 에서는 $51.8 \mathrm{~dB} \mathrm{HL}(\mathrm{SD}=$

Table 1. Demographic characteristics and pretrial THI scores of each group

\begin{tabular}{lcccc}
\hline Group & Male & Female & Age (years) & Pretrial THI scores (\%) \\
\hline BBN & $\mathrm{n}=3$ & $\mathrm{n}=4$ & $72.4(\mathrm{SD}= \pm 7.1)$ & $39.3(\mathrm{SD}= \pm 11.3)$ \\
Nature & $\mathrm{n}=7$ & $\mathrm{n}=5$ & $73.8(\mathrm{SD}= \pm 6.7)$ & $33.0(\mathrm{SD}= \pm 18.4)$ \\
\hline
\end{tabular}
THI: Tinnitus Handicap Index, BBN: broadband noise, SD: standard deviation \pm 17.8)로 나타났다. 두 그룹 간 통계적 검정력을 확보하기 위 하여 무작위 할당 방식으로 그룹을 설정하였으나 광대역 소음 기반 그룹에서 5 명의 대상자가 중도 포기하였기에 최종 분석 그룹 간 조건의 유사성을 확인하기 위하여 광대역 소음 기반 재활 그룹과 자연음 기반 재활 그룹 간의 연령 분포, 초기 이명 장애지수 설문지 점수 및 청력 역치 차이 유무를 독립표본 $t$ 검 정(independent $t$-test)으로 확인하였다. 독립표본 $t$ 검정 결과 두 그룹 간 연령 $(p=0.717)$ 및 초기 이명장애지수 설문지 점수 $(p=0.427)$ 에서 모두 유의미한 차이가 나타나지 않았으며, 3 분법(기도 청력 역치 $500 \mathrm{~Hz}, 1,000 \mathrm{~Hz}, 2,000 \mathrm{~Hz}$ 의 평균)에 의거한 순음청력검사 결과 오른쪽 청력 $(p=0.292)$, 왼쪽 청력 ( $p=0.684)$ 모두 두 그룹 간 유의미한 차이가 나타나지 않았다. 일반적으로 이명의 기간 및 이명 소리 특성에 따른 소리치료 효 과는 상관성이 낮은 것으로 보고하고 있어 본 연구에서는 그룹 의 유사성 구분을 위한 요소로 분석하지 않았다(Sharma et al., 2018).

각 그룹의 이명 특징은 Table 2에 제시하였다. 광대역 소음 기반 재활 그룹의 경우, 이명이 $125 \mathrm{~Hz}$ 와 유사하다고 보고한 인원은 1 명이었으며, $250 \mathrm{~Hz}$ 와 유사하다고 보고한 인원은 1 명, $750 \mathrm{~Hz}$ 와 유사하다고 보고한 인원은 2명, $4,000 \mathrm{~Hz}$ 와 유사하 다고 보고한 인원은 2명, 그리고 $6,000 \mathrm{~Hz}$ 와 유사하다고 보고 한 인원은 1 명으로 나타났다. 이명의 소리 유형으로는 비행기 소리(1명), ‘삐' 소리(1명), '윙윙’거리는 혹은 '와글와글'거리는 소 리(1명), 매미 소리(1명), 기계 소리(1명), 바람 소리(1명), 그리고

Table 2. Pitch and sound feature of tinnitus for participants

\begin{tabular}{|c|c|c|}
\hline & BBN group $(n=7)$ & Nature group $(\mathrm{n}=12)$ \\
\hline \multicolumn{3}{|l|}{ Pitch } \\
\hline $125 \mathrm{~Hz}$ & $\mathrm{n}=1$ & $\mathrm{n}=0$ \\
\hline $250 \mathrm{~Hz}$ & $\mathrm{n}=1$ & $\mathrm{n}=2$ \\
\hline $750 \mathrm{~Hz}$ & $\mathrm{n}=2$ & $\mathrm{n}=3$ \\
\hline $1,000 \mathrm{~Hz}$ & $\mathrm{n}=0$ & $\mathrm{n}=0$ \\
\hline $1,500 \mathrm{~Hz}$ & $\mathrm{n}=0$ & $\mathrm{n}=1$ \\
\hline $2,000 \mathrm{~Hz}$ & $\mathrm{n}=0$ & $\mathrm{n}=1$ \\
\hline $4,000 \mathrm{~Hz}$ & $\mathrm{n}=2$ & $\mathrm{n}=1$ \\
\hline $6,000 \mathrm{~Hz}$ & $\mathrm{n}=1$ & $\mathrm{n}=4$ \\
\hline \multicolumn{3}{|c|}{ Feature of tinnitus } \\
\hline & Airplane sound $(\mathrm{n}=1)$ & $\operatorname{Beep}(n=1)$ \\
\hline & Beep $(n=1)$ & Buzzing $(\mathrm{n}=1)$ \\
\hline & Buzzing $(\mathrm{n}=1)$ & Cricket $(n=1)$ \\
\hline & Cicadas $(\mathrm{n}=1)$ & Hissing $(\mathrm{n}=1)$ \\
\hline & Machine sound $(\mathrm{n}=1)$ & Machine sound $(\mathrm{n}=1)$ \\
\hline & Wind blowing $(\mathrm{n}=1)$ & Ocean $(n=1)$ \\
\hline & Whistling $(\mathrm{n}=1)$ & Rustling $(\mathrm{n}=1)$ \\
\hline & & Wind blowing $(\mathrm{n}=4)$ \\
\hline & & Whistling $(\mathrm{n}=1)$ \\
\hline
\end{tabular}


휘파람 소리(1명)로 보고하였다. 자연음 기반 재활 그룹의 경우 이명이 $250 \mathrm{~Hz}$ 와 유사하다고 보고한 인원은 2명이었으며, 750 $\mathrm{Hz}$ 와 유사하다고 보고한 인원은 3명, $1,500 \mathrm{~Hz}$ 와 유사하다고 보고한 인원은 1명, $2,000 \mathrm{~Hz}$ 와 유사하다고 보고한 인원은 1명, $4,000 \mathrm{~Hz}$ 와 유사하다고 보고한 인원은 1명, 그리고 $6,000 \mathrm{~Hz}$ 와 유사하다고 보고한 인원은 4명으로 나타났다. 이명의 소리 유형으로는 ‘삐' 소리(1명), ‘윙윙거리는 혹은 ‘와글와글'거리는 소리(1명), 귀뚜라미 소리(1명), “쉿’ 소리(1명), 기계 소리(1명), 바 다 소리(1명), 바스락거리는 소리(1명), 바람 소리(4명), 그리고 휘 파람 소리(1명)로 보고하였다.

\section{Research design}

본 연구는 연구 참여자를 대상으로 3개월간 광대역 소음 및 자연음 기반 재활 그룹으로 나누어 부분 차폐 방식의 소리치료 를 시행하고 재활 전후의 이명장애지수 설문지 점수의 변화 정 도를 비교하고자 하였다. 각 그룹의 이명 재활은 총 4회(재활 시작 전 및 재활 시작 후 $1,2,3$ 개월 차)의 상담 과정을 포함하 여 3개월간의 소리치료를 시행하였으며, 소리치료는 모든 대상 자가 하루 평균 3 시간 이상 시행하도록 권고하였다. 1 회 차(재 활 시작 전)와 4회 차(재활 종료 후)에 이명장애지수 설문지를 통한 평가를 진행하였다. 재활 시작 전의 상담은 대상자의 청력 상태, 이명도 검사 결과 및 이명장애지수 설문지 점수의 해석과 이명의 원인 및 특징을 포함한 이명에 대한 전반적인 정보, 부 분 차폐 방식 소리치료의 방법과 효과에 대한 안내를 포함하여 진행하였다. 재활 시작 후의 상담은 소리치료 과정에서 발생하 는 어려움, 소리치료 음원의 강도 설정 방법 교육 및 지속적인 소리치료 음원 청취의 중요성을 포함하여 대상자가 소리치료 과 정에서 겪는 어려움과 궁금증에 대한 답변을 포함하여 진행하 였다. 정기 상담 시기 외에도 대상자가 상담을 원할 시에는 전
화 상담을 상시 진행하였다.

부분 차폐 방식의 소리치료는 각 연구 참여자의 휴대전화에 소리치료 음원을 저장하여 이어폰을 통해 청취하도록 하여 진 행하였다. 일반적으로 소리치료는 $10,000 \mathrm{~Hz}$ 이상의 광범위한 주파수 범위를 가진 광대역 음원을 소리치료 음원으로 사용하 도록 권고하고 있어(Barozzi et al., 2016; Henry et al., 2004), 본 연구에서는 $12,000 \mathrm{~Hz}$ 의 범위로 소리치료 음원을 제작하였 다. 또한, 본 연구에서 사용된 자연음은 전 주파수에 걸쳐 진폭 이 유사하게 분포하고 재생 시간에 따라 진폭 변화가 역동적인 특성이 있는 음원을 선택 기준으로 하여 선정하였다(Henry et al., 2004). 광대역 소음 그룹과 자연음 그룹의 음원 간 조건을 최대한 유사하게 설정하기 위해 백색 소음과 자연음을 12,000 $\mathrm{Hz}$ 저주파수 통과 필터(low-pass filter)로 필터링하여 제작한 음원(광대역 소음, 파도 소리, 시냇물 흐르는 소리)을 사용하였 으며, 모든 음원의 샘플링 속도는 $44,100 \mathrm{~Hz}$ 의 동일한 조건으 로 설정하였다. 소리치료에 사용한 음원에 대한 예시로 광대역 소음과 파도 소리의 주파수 특성을 Figure 1에 제시하였다. 광 대역 소음과 파도 소리 모두 상대 평균 실효값(relative rootmean square)은 $-30 \mathrm{~dB}$ 이었다. 광대역 소음의 경우 주파수별 진폭의 변화는 상대 평균 실효값을 기준으로 약 $1.3 \mathrm{~dB}$ 이었다. 파도 소리의 경우에는 주파수별 진폭의 변화는 상대 평균 실효 값을 기준으로 약 $10.1 \mathrm{~dB}$ 의 편차가 나타났으나 자연음의 특성 상 주파수별 진폭의 변화는 자연스러운 특성이며 전체 상대 평 균 실효값은 $-30 \mathrm{~dB}$ 로 광대역 소음과 유사하다고 볼 수 있다. 소리치료 음원의 강도는 연구 참여자의 휴대전화에 연결된 이 어폰을 양이로 착용하고 소리치료 음원의 강도를 완전 차폐 강 도에서 낮추면서 연구 참여자가 이명 소리와 소리치료 음원이 동시에 인지되는 강도 중에 대상자가 선호하는 최소 레벨을 기 준으로 설정하였다(Jastreboff, 2000). 만약 연구 참여자가 소리
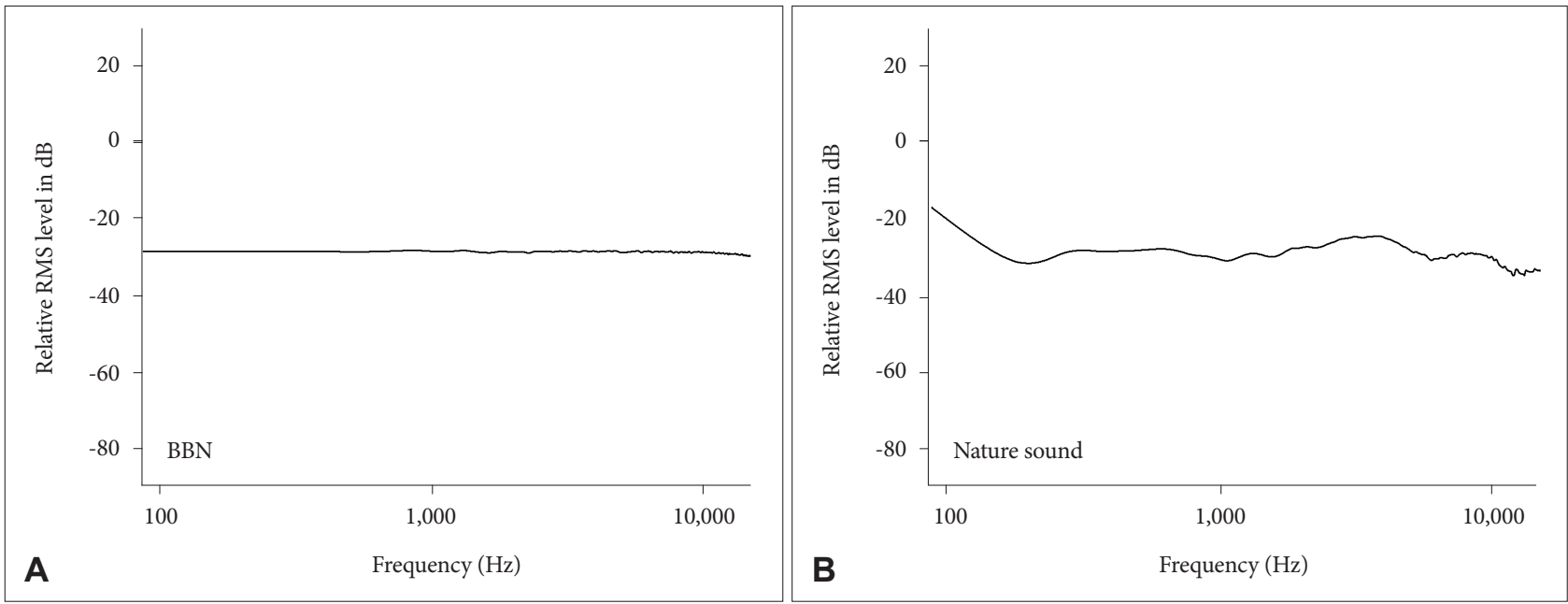

Figure 1. RMS levels for BBN $(A)$ and nature sound $(B)$ as a function of frequency. RMS: relative root-mean square, BBN: broadband noise. 
치료 음원의 강도가 크다고 호소하면 대상자가 불편하지 않게 청취 가능한 레벨까지 강도를 낮추어 크기를 설정하였다(Tyler et al., 2012). 소리치료 음원의 청취 시간은 연구 참여자가 원하 는 만큼 청취하되 30 분 길이로 저장된 소리치료 음원의 재생이 끝나면 30분 이상 간격을 두고 다시 재생하도록 교육하였다 (Tyler et al., 2012).

이명 재활 효과의 확인은 각 재활 그룹별 재활 전후의 이명 장애지수 설문지 점수와 효과 크기(effect size)의 변화를 기준 으로 진행하였다. 이명장애지수 설문지는 이명으로 인한 대상자 의 심리 및 기능적 영향을 포함하여 대상자가 이명으로 인해 겪 는 어려움 정도를 종합하여 평가하는 25 개의 설문으로 구성되 어 있는 설문지이다(Kim et al., 2002). 설문지 점수의 총점은 100점으로 총 점수가 높을수록 이명으로 인한 불편함이 크다 는 것을 의미한다. 이명 설문지 점수 변화에 따른 재활 효과 크 기는 관련 연구들에서 보고된 결과값들을 표준화한 통계 범위 를 의미한다(Cohen, 1988). 일반적으로 효과 크기 값이 0.2 이하 일 경우에는 재활 효과의 크기가 작은(small effect) 것으로 해석 하며, 0.3 에서 0.5 사이는 재활 효과의 크기가 보통(moderate effect)인 것으로 해석할 수 있으며, 0.8 이상은 재활 효과가 큰 (large effect) 것으로 해석할 수 있다. 또한, 효과 크기 값이 클수 록 재활 효과가 높은 것으로 해석할 수 있다.

\section{Statistical analysis}

본 연구는 각 그룹별 이명 재활 전후의 이명장애지수 설문지 점수의 변화를 비교하기 위하여 Wilcoxon 부호-서열 검정(Wilcoxon signed-rank test)을 사용하였다. 또한, 이명 재활 전후 에 따른 재활 효과의 크기 검정을 위해 코헨의 효과 크기(Cohen's d)를 사용하였다. 코헨의 효과 크기는 집단 간의 평균 차이를 표준편차로 나누어 계산한 값이며, 그룹 간 차이의 정도를 수 치화하여 직접적으로 비교할 수 있고 표본 수에 영향을 받지 않는다는 장점이 있다(Nahm, 2015). Wilcoxon 부호-서열 검정 에 사용된 소프트웨어는 SPSS-22 (IBM Corp., Armonk, NY, USA)였다. 코헨의 효과 크기에 사용된 소프트웨어는 콜로라도 대학교(University of Colorado)에서 제공하는 효과 크기 계산 기(effect size calculator) 프로그램(1998년도 Lee A. Becker에 의해 개발)을 이용하였다(https://www.uccs.edu/ lbecker/).

\section{RESULTS}

본 연구는 상담과 광대역 소음 기반 부분 차폐 방식의 소리 치료 재활 그룹과 상담과 자연음 기반 부분 차폐 방식의 소리치 료 재활 그룹으로 나누어 3 개월간 이명 재활을 시행하고 재활 시행 전후에 작성한 이명장애지수 설문지 점수를 비교하여 소
리치료 음원 특성에 따른 재활 효과를 비교하였다(Figure 2). 자 연음 기반 재활 그룹의 이명장애지수 설문지 평균 점수는 재활 전 33.0점 $(\mathrm{SD}= \pm 18.40)$ 에서 재활 후 17.08점 $(\mathrm{SD}= \pm 11.48)$ 으 로 평균 15.92점(33.0 17.08)의 재활 효과를 보였고 기능(functional), 감정(emotional), 재앙화(catastrophic) 범주 점수에서 모 두 통계적으로 유의미한 감소로 나타났다 $(p<0.05)$. 광대역 소음 기반 재활 그룹의 경우 이명장애지수 설문지의 하위 범주 인 기능 범주에서 유의미한 차이를 보였으나 $(p<0.05)$, 감정 범주 $(p=0.202)$ 및 재앙화 범주 $(p=0.084)$ 점수에서 통계적으 로 유의미하지 않은 차이가 나타났으며, 평균 점수는 재활 전 39.29점 $(\mathrm{SD}= \pm 11.32)$ 에서 재활 후 30.86점 $(\mathrm{SD}= \pm 16.96)$ 으 로 평균 8.43점(39.29 30.86)의 재활 효과로 이는 통계적으로 유의미하지 않은 차이였다 $(p=0.061)$.

Wilcoxon 부호-서열 검정은 비모수 검정으로 비교하고자 하 는 두 값의 평균값 간의 유의미한 차이 여부를 확인할 수 있는 검정 방식이지만 유의미한 차이에 대한 효과의 크기를 파악할 수 없는 한계가 있어, 각 그룹의 재활에 따른 효과의 크기를 확 인하기 위하여 코헨의 효과 크기를 계산하였다. 그 결과, 자연음 기반 재활 그룹의 이명장애지수 설문지 점수의 재활 전후 변화 의 효과 크기 값은 1.03 으로 큰 효과로 나타났다. 광대역 소음 기반 재활 그룹의 이명장애지수 설문지 점수의 재활 전후 변화 의 효과 크기 값은 0.58 로 보통 효과로 나타났다.

\section{DISCUSSIONS}

본 연구는 부분 차폐 방식의 소리치료를 적용한 3개월간의 이명 재활에서 사용되는 소리 음원(자연음 및 광대역 소음)에 따른 이명 재활의 효과를 비교해 보고자 하였다. 재활 효과의

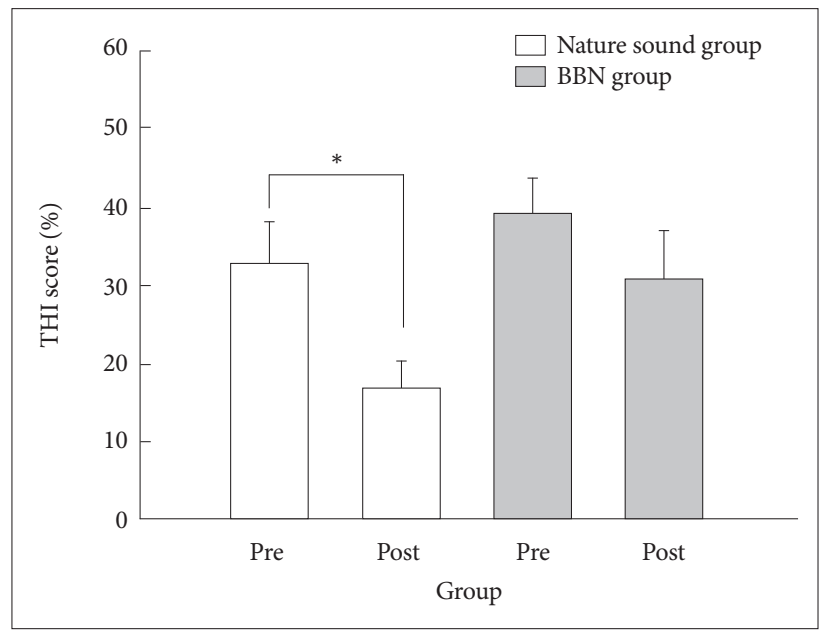

Figure 2. THI scores of pre- and post-treatment for the nature sound therapy group and the BBN therapy group. Asterisks represent the statistical significance. THI: Tinnitus Handicap Index, BBN: broadband noise. 
측정은 재활 전후의 그룹별 이명장애지수 설문지 점수 변화를 기준으로 진행하였다. 연구 결과, 자연음 기반 재활 그룹의 재활 전후 설문지 점수는 평균 15.92점 감소하였으며, 광대역 소음 기반 재활 그룹의 설문지 점수는 평균 8.43점 감소하였다. 또한, 이명 재활의 효과 크기는 자연음 기반 재활 그룹의 경우에는 1.03 으로 큰 효과로 나타났으며, 광대역 기반 재활 그룹의 경우 에는 0.58 로 보통 효과로 나타났다.

본 연구에 참여한 대상자의 이명 재활 전후에 따른 개인별 재활 효과를 확인하기 위하여 각 연구 참여자의 재활 전후 이명 장애지수 설문지 점수를 Figure 3에 제시하였다. 광대역 소음 기반 재활 그룹의 경우, 3 개월간의 재활을 완수한 7 명 중 2 명은 재활 전후의 설문지 점수가 10점 이상 감소하였고, 4 명은 10 점 미만으로 감소하였으며 1 명의 참여자는 오히려 6점이 증가하였 다(재활 전: 54점, 재활 후: 60점). 자연음 기반 재활 그룹의 경 우, 총 12 명 중 7 명은 재활 전후의 설문지 점수 감소 정도가 10 점 이상이었으며 3 명은 10 점 미만이었다. 나머지 2 명의 참여자 는 재활 전후의 설문지 점수 변화가 없었다. Figure 3 의 결과는 두 그룹 모두 재활 전 이명으로 인한 불편함의 정도가 다양한 대상자에게서 자연음 및 광대역 소음 기반 재활 그룹 대부분에 게서 재활 효과가 나타났다고 볼 수 있다. 하지만 재활 효과의 정도 측면에서 자연음 기반의 소리치료를 적용한 대상자가 광 대역 소음 기반의 소리치료 적용 대상자보다 더 높은 재활 효 과가 나타났음을 확인할 수 있다. 앞서 서론에서 언급한 Henry et al.(2004)의 연구에서는 이명이 인지되는 상태의 대상자에게 소음과 자연음을 들려주고 즉각적인 이명의 완화 정도를 측정 하여 자연음을 들려주었을 때 이명의 완화 효과가 더 두드러진 다고 보고하였다. 두 연구의 결과를 종합하면 자연음 형태의 음원이 소음 형태의 음원보다 이명의 즉각적인 완화 및 이명

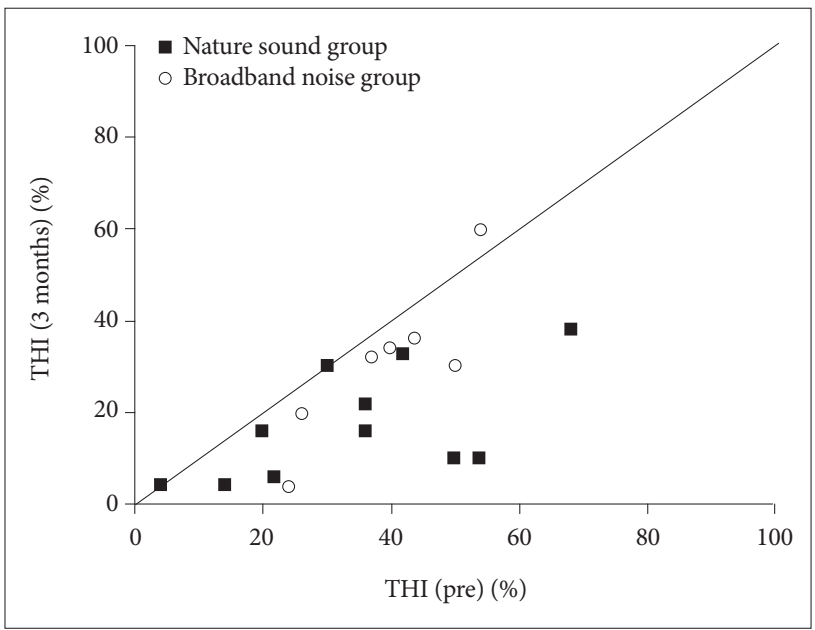

Figure 3. THI scores of pre- and post-treatment for each of the two groups. The diagonal line indicates no THI score change between pre- and post-treatment. THI: Tinnitus Handicap Index.
재활에 따른 불편함 감소에 긍정적인 영향을 주었다고 볼 수 있다. 관련 선행연구 및 본 연구에서 제시한 재활 효과의 통계 적 유의미성, 크기 효과, 그리고 개인별 이명설문지 점수 변화 결과를 고려하였을 때, 적어도 소리 특성에 따라 이명 재활 효 과가 영향을 받을 수 있음을 알 수 있다. 소리치료 전후에 시행 한 이명장애지수 설문지 점수의 변화가 컸던 대상자 및 점수가 재활 후에 오히려 증가한 대상자의 특성을 분석한 결과 청력 및 이명 특성과의 연관성이 발견되지 않았다. 자연음 기반 재활 그룹의 경우 재활 전과 비교하여 재활 후에 2 명의 대상자가 이 명장애지수 설문지 점수가 40점 이상 감소하였으나 다른 그룹 내 인원들과의 특성 차이가 발견되지 않았다. 특히 차폐를 활용 한 소리치료의 경우 잔여억제(residual inhibition) 반응 여부가 재활 효과에 영향을 줄 수 있으나(Vernon \& Schleuning, 1978), 점수가 크게 감소한 2 명의 경우 잔여억제 반응이 나타나지 않은 것으로 보아 선형적인 상관관계를 발견할 수 없었다. 광대역 소 음 기반 재활 그룹의 경우 재활 전과 비교하여 오히려 점수가 6 점이 증가한 대상자가 1 명이 있었지만, 해당 대상자 또한 그룹 내 인원들과의 특성 차이가 발견되지 않았다. 점수가 증가한 1 명의 경우 잔여억제 반응이 나타났는데 이 또한 본 연구에 참 가한 대상자의 데이터를 기준으로 보면 잔여억제 반응과 이명 재활 효과 간의 선형적 상관성은 나타나지 않았다.

광대역 소음 기반 그룹에서 총 12 명의 연구 참가자 중에 5 명 이 재활을 도중에 중단하였다. 중단의 이유로는 소리치료 음원 (광대역 소음)에 대한 거부감을 보고한 인원이 3명이었고, 휴대 전화 사용에 따른 불편함을 호소한 인원이 1명이었다. 나머지 1 명은 공개할 수 없는 개인적인 사유로 중단했다고 응답하였다. 이명 재활 관련 연구에서 중도 중단은 일반적인 현상이다. Tyler et al.(2012)은 상담 그룹, 상담과 차폐 소리치료 그룹, 이명재훈련 치료 그룹으로 나누어 18 개월 동안 재활을 시행하였는데 상담 그룹은 20명 중 2 명, 상담과 차폐 소리치료 그룹은 19 명 중 8 명, 그리고 이명재훈련치료 그룹은 24명 중 5명이 재활을 도중에 중 단하였다. 본 연구에서 5 명의 재활 중단 대상자 중 3 명이 소리치 료 음원(광대역 소음)에 대한 거부감을 이유로 재활 기간 중 중 단했지만, 자연음 기반 재활 그룹의 경우에 중단자가 없었다는 사실은 자연음이 소음과 비교하면 소리에 대한 거부감이 다소 적었다고 볼 수 있다. 하지만 본 연구의 결과만을 가지고 모든 대상자에게 광대역 소음이 자연음보다 재활 효과가 낮거나 거 부감이 크다고 일반화하여 해석하기에는 대상자 수가 적다고 볼 수 있다.

본 연구는 몇 가지 한계점을 가지고 있다. 첫째, 본 연구에 참 여한 연구 참여자의 수가 다소 적었다(그룹당 7 명 및 12 명). 이명 재활 관련 연구는 대상자 수의 범위가 매우 넓은 편이다. Henry et al.(2007)은 그룹별로 83 93명의 연구 참여자를 대상으로 연구 
를 시행하였고, Herraiz et al.(2005)의 경우에는 그룹별로 21 68명의 연구 참여자를 대상으로 연구를 시행하였다. 또한, Tyler et al.(2012)은 그룹별로 11 19명의 연구 참여자를 대상으로 연 구를 진행하였다. 선행연구들의 그룹별 인원보다 본 연구의 대 상자 수가 적었지만 이러한 한계를 보완하기 위해 통계적 유의 미성 비교와 더불어 효과 크기를 측정하여 제시하였다. 효과 크기는 일반적인 통계 기법(유의미성 확인)이 비교군과의 적은 값 차이로도 대상자 수가 증가하면 유의미한 결과가 나오는 한 계점을 보완하기 위한 대안으로 활용할 수 있으며, 대상자 수와 무관하게 평균과 표준편찻값을 가지고 재활 효과의 크기를 확 인할 수 있다(Cohen, 1988). 이명 재활 연구에서 적절한 대상자 수를 정의하는 것은 어려운 일이지만 통계적 유의미성과 더불 어 효과 크기를 함께 비교한다면 재활 효과에 대한 효과적인 분석이 이루어질 수 있을 것이다. 다음으로 본 연구는 3개월의 단기간 재활 효과만을 측정하여 12 개월 이상의 장기적 재활에 따른 효과를 측정하지 못했다. 장기적인 관점에서 재활의 효과 를 측정한 연구들은 보통 12 개월 또는 18 개월을 기준으로 그 결과를 제시하고 있다(Henry et al., 2007; Tyler et al., 2012). 따라서 향후에는 장기적인 재활 기간에 따른 재활 효과 연구가 진행된다면 자연음 사용에 따른 소리치료의 장기적인 재활 효 과 확인이 가능할 것이다. 셋째, 본 연구는 소리치료 음원을 대 상자의 휴대전화에 저장하여 청취하는 방식으로 이루어졌다. 하 지만 연구 참여자가 휴대전화 사용에 익숙하지 않다면 불편함 을 초래할 수 있어 향후 연구에서는 사용이 편리한 인터페이스 의 어플리케이션을 적용한다면 사용의 불편함에 따른 중도 포 기율을 줄일 수 있을 것이다.

증가하는 주관적 만성 이명 대상자를 위한 다양한 방식의 소리치료법이 제안되고 그 효과들이 연구 결과로 제시되고 있 지만, 이명의 재활 효과는 방법의 차이뿐만 아니라 사용되는 소리치료 음원에 따라서도 달라질 수 있다. 따라서 개인의 선호 도 및 편안함을 고려한 소리치료 음원을 적용하여 이명 재활을 진행한다면 더욱 긍정적인 재활 효과를 기대할 수 있을 것이다. 자연음은 소음 기반 소리치료음에 불편함을 호소하는 대상자 에게 적용 가능한 대안이 될 수 있을 것이다.

중심 단어 : 이명·차폐·이명 재활·소리치료·주관적 이명 치료.

\section{Ethical Statement}

The study was approved by the Institutional Review Board of Hallym University (HIRB-2017-111).

\section{Acknowledgments} N/A

\section{Declaration of Conflicting Interests}

There are no conflict interests.

\section{Funding}

This work has supported by the National Research Foundation of Korea (NRF) grant funded by the Korea government (MSIT) (NRF-2018 R1C1B6003765).

\section{REFERENCES}

Barozzi, S., Del Bo, L., Crocetti, A., Dyrlund, O., Passoni, S., Zolin, A., et al. (2016). A comparison of nature and technical sounds for tinnitus therapy. Acta Acustica united with Acustica, 102(3), 540-546.

Cohen, J. (1988). Statistical Power Analysis for the Behavioral Sciences. (2nd ed.), (pp. 20-26) New York, NY: Lawrence Erlbaum Associates.

Del Bo, L., Baracca, G., Forti, S., \& Norena, A. (2010). Sound stimulation. In Møller, A. R., Langguth, B., DeRidder, D., \& Kleinjung T. Textbook of Tinnitus (pp. 597-604). New York, NY: Springer Science \& Business Media.

Hazell, J. W. \& Wood, S. (1981). Tinnitus masking-a significant contribution to tinnitus management. British Journal of Audiology, 15(4), 223230.

Henry, J. A., Loovis, C., Montero, M., Kaelin, C., Anselmi, K. A., Coombs, R., et al. (2007). Randomized clinical trial: Group counseling based on tinnitus retraining therapy. Journal of Rehabilitation Research and Development, 44(1), 21-32.

Henry, J. A., Rheinsburg, B., \& Zaugg, T. (2004). Comparison of custom sounds for achieving tinnitus relief. Journal of the American Academy of Audiology, 15(8), 585-598.

Henry, J. A., Schechter, M. A., Zaugg, T. L., Griest, S., Jastreboff, P. J., Vernon, J. A., et al. (2006). Clinical trial to compare tinnitus masking and tinnitus retraining therapy. Acta Oto-Laryngologica, Supplement, (556), 64-69.

Herraiz, C., Hernandez, F. J., Plaza, G., \& de los Santos, G. (2005). Longterm clinical trial of tinnitus retraining therapy. Otolaryngology-Head and Neck Surgery, 133(5), 774-779.

Jastreboff, P. J. (1990). Phantom auditory perception (tinnitus): Mechanisms of generation and perception. Neuroscience Research, 8(4), 221254.

Jastreboff, P. J. (2000). Tinnitus habituation therapy (THT) and tinnitus retraining therapy (TRT). In Tyler, R. S. Tinnitus Handbook (pp. 357-376). SanDiego, CA: Singular Publishing Group.

Jastreboff, P. J. \& Hazell, J. W. (1993). A neurophysiological approach to tinnitus: Clinical implications. British Journal of Audiology, 27(1), 7-17.

Jastreboff, P. J. \& Jastreboff, M. M. (2006). Tinnitus retraining therapy: A different view on tinnitus. ORL: Journal for Oto-Rhino-Laryngology and its Related Specialties, 68(1), 23-29; discussion 29-30.

Kim, J. H., Lee, S. Y., Kim, C. H., Lim, S. L., Shin, J. N., Chung, W. H., et al. (2002). Reliability and validity of a Korean adaptation of the Tinnitus Handicap Inventory. Korean Journal of Otorhinolaryngology-Head and Neck Surgery, 45(4), 328-334.

Lugli, M., Romani, R., Ponzi, S., Bacciu, S., \& Parmigiani, S. (2009). The windowed sound therapy: A new empirical approach for an effectiv personalized treatment of tinnitus. The International Tinnitus Journal, 15(1), 51-61.

Nahm, F. S. (2015). Understanding effect sizes. Hanyang Medical Reviews, 35(1), 40-43.

Robinson, S. K., Viirre, E. S., \& Stein, M. B. (2007). Antidepressant therapy in tinnitus. Hearing Research, 226(1-2), 221-231.

Sharma, A., Munjal, S., Panda, N., \& Mohanty, M. (2018). Demographic variations in tinnitus subjects with and without hearing loss: A study of 175 subjects. The International Tinnitus Journal, 22(1), 77-83.

Tunkel, D. E., Bauer, C. A., Sun, G. H., Rosenfeld, R. M., Chandrasekhar, S. S., Cunningham, E. R. Jr., et al. (2014). Clinical practice guideline: Tin- 
nitus. Otolaryngology-Head and Neck Surgery, 151(2 Suppl), S1-S40.

Tyler, R. S., Noble, W., Coelho, C. B., \& Ji, H. (2012). Tinnitus retraining therapy: Mixing point and total masking are equally effective. Ear and Hearing, 33(5), 588-594.

Vernon, J. (1977). Attempts to relieve tinnitus. Ear and Hearing, 2(4), 124131.
Vernon, J. \& Schleuning, A. (1978). Tinnitus: A new management. The Laryngoscope, 88(3), 413-419.

World Health Organization. (2001). International classification of functioning disability and health: Final draft, full version: ICIDH-2. Geneva: World Health Organization. 